\title{
Inappropriate sexual behaviors and Mirtazapine treatment in Autism Spectrum Disorders: A case report
}

\section{Otizmde Spektrum Bozukluklarında uygunsuz cinsel davranışlar ve Mirtazapin tedavisi: Bir Olgu Sunumu}

\author{
Şahin Bodur ${ }^{1}$ (D), Hesna Gul ${ }^{1 *}$ (D), Burcu Ersöz Alan ${ }^{2}$ (D), Ozgun Ture Tekin ${ }^{1}$ (D), \\ Mehmet Ayhan Congologlu ${ }^{1}$ \\ 1 Department of Child and Adolescent Psychiatry, Gülhane Training and Research Hospital, Ankara, Turkey \\ ${ }^{2}$ Department of Child and Adolescent Psychiatry, Hacettepe University Faculty of Medicine, Ankara, Turkey \\ * Corresponding author: Hesna Gül E-mail: drhesnagul@gmail.com ORCID: 0000-0002-1696-1485 \\ Received: 18 February 2019 Accepted: 14 May 2019
}

\begin{abstract}
Autism spectrum disorder is characterized by patterns of delay and deviance in the development of social, communicative, and cognitive skills that arise in the first years of life. Although many approaches were investigated for the behavioral problems in ASD, investigations of the treatment of inappropriate sexual behaviors (ISB) were still so rare. Mirtazapine has been a promising intervention for the ISB which do not decrease with behavioral interventions recently. In this case, we aimed to present the dramatic benefit of mirtazapine in a 14-year-old autistic boy with inappropriate sexual behaviors.
\end{abstract}

Keywords: sexual behaviors, autism, mirtazapine

\section{öz}

Otizm spektrum bozukluğu, yaşamın ilk yıllarında ortaya çıkan sosyal, iletişimsel ve bilişsel becerilerin gelişiminde gecikme ve sapma ile karakterize bir bozukluktur. OSB'deki davranışsal problemler için birçok yaklaşım araştııımış olmasına rağmen, uygunsuz cinsel davranışların (UCD) tedavisine ilişkin araştırmalar hala çok nadirdir. Mirtazapin, son zamanlarda davranışsal müdahalelerle azalmayan UCD için umut verici bir müdahale olmuştur. Bu yazıda, uygunsuz cinsel davranışları olan 14 yaşındaki otistik bir çocukta mirtazapinin dramatik faydasını sunmayı amaçladık.

Anahtar kelimeler: cinsel davranışlar, otizm, mirtazapin 


\section{INTRODUCTION}

Autism spectrum disorder (ASD) is described by early onset behaviors of social communication deficit and repetitive sensory-motor behaviors with strongly genetic but mostly unknown causes [1]. In the United States, the prevalence of ASD is $59(1,7 \%)$ and it's most diagnosed in preschool years [2]. Although the core symptoms of ASD has not been treated by any of the medications yet, prescription is given for the associated symptoms like irritability, aggression, selfinjurious behaviors, anxiety, hyperactivity, impulsivity, inattention, and insomnia [3].

Inappropriate sexual behaviors (ISB) are also reported as associated behaviors of ASD. Masturbation and fetishism in public, and touching other people's genital regions are common examples. These are thought to be caused by the lack of social awareness, reciprocal interaction, adaptive social behaviors, and interpreting social cues and considered as self-stimulatory behaviors to reduce sexual tension [4].

Although ISB in ASD are distressing situations for the patient, family and environment, only few articles on the subject has been published [4-10].

While psychoeducation programs and behavior therapy have been proposed as an effective first-line intervention to prevent and treat ISB, pharmacological treatment could be needed when these programs failed. However, still little is known about medication of ISB in ASD [11].

Mirtazapine may be helpful in curbing excessive masturbation and other inappropriate sexual behaviors in children and adolescents with ASD.

\section{CASE PRESENTATION}

One year ago, a 14 year-old boy diagnosed with ASD and has been taken special education since he was 2 years old, admitted to our hospital with complaints of irritability, aggression, and self-injurious behavior (biting his hands, hitting his head) and was prescribed aripiprazole $6 \mathrm{ml} /$ day. ISB was described for the last six months and was seen everyday in public for the last month. He wanted to touch the people whose feet were bare and then started to masturbate. The family was so distressed, they could not go anywhere. Although behavioral interventions were applied, nothing was changed. During his psychiatric examination, he was very irritable without any eye contact, making meaningless sounds, biting his hands, did not obey any commands. He could not speak. Psychiatric history of the family was normal. Netrolex $500 \mathrm{mg} /$ day was prescribed for epilepsy one year ago. Although last EEG was abnormal, no epileptic seizure was seen clinically. During psychometric evaluation, he could not cooperate during the administration of the Stanford-Binet test. According to clinical judgments of autors and the psychologist, he had moderate mental retardation. Because behavioral interventions were ineffective, mirtazapine $15 \mathrm{mg} /$ day was started for ISB. The family telephoned two days later and told that ISB decreased and he slept comfortably for the last two nights. After one month ISB disappeared completely. The score of Clinic Global Impression Scale (CGI) was 7 at the first examination while it was 2 after one month. His followup has continued.

\section{DISCUSSION}

Although many approaches were investigated for the behavioral problems in ASD, investigations of the treatment of ISB were still so rare. This case represented a boy diagnosed with ASD who suffered from fetishism and masturbation in public. Cases like our one, ASD with sexual behaviors, are rare in literature. Because sexual behaviors trouble the caregiver, family and community, treatment become more important. There are studies shown the ineffectiveness of psychoeducation and behavioral interventions [12]. Pharmacological treatments could be preferred in those cases. To date, many medications were used and there are only 7 case reports and one case series study in literature $[5,9,11,13]$.

Mirtazapine has been a promising intervention for the ISB which do not decrease with behavioral interventions recently.

Mirtazapine has both noradrenergic and serotonergic properties. By blocking the presynaptic a2-adrenergic receptor (autoreceptors), it increases norepinephrine (NE) and NE facilitates serotonin (5-HT) release via a1-adrenergic receptors on 5-HT neurons. a2-adrenergic antagonism of mirtazapine at the presynaptic a2-adrenoreceptor on 5-HT neurons (Heteroceptors) facilitates this action. Mirtazapine also blocks 5-HT2 and 5-HT3 receptors which is responsible of its anxiolytic and hypnotic properties. Its activating (5HT2) and gastrointestinal (5-HT3) side effects rare. Mirtazapine has a half-life of $20-40$ hours. Potential pharmacokinetic drug-drug interactions with mirtazapine are minimal. Although laboratory monitoring is not recommended during the mirtazapine treatment, elevations in liver enzymes and lipids have been reported. Agronulocytosis is rare [14]. 
In our case mirtazapine was used, because behavioral interventions were tried and found ineffective. Mirtazapine was effective for both ISB and sleep problems in our patient. It was chosen for this case because of its serotonergic and antilibidinal effects at the low doses. There are also case studies with SSRI, nevertheless we preferred mirtazapine because of the side effects of behavioral inhibition, insomnia, aggression of SSRI [13].

This case confirms the effectiveness of mirtazapine at ASD with ISB as shown at previous case studies. Mirtazapine is an antidepressant agent which has been using for a long time and affects serotonergic at low doses and noradrenergic at high doses.

Mirtazapine could become an important psychopharmacological agent in cases of ASD with ISB. However, only case reports have been published in literature yet. Further research with placebo controlled, double-blind studies should be performed.

\section{DECLARATION OF CONFLICT OF INTEREST}

The authors received no financial support for the research and/or authorship of this article. There is no conflict of interest.

\section{REFERENCES}

1. Lord C, Elsabbagh M, Baird G, Veenstra-Vanderweele J. Autism spectrum disorder. The Lancet. 2018.

2. Bennett AE, Miller JS, Stollon N, Prasad R, Blum NJ. Autism Spectrum Disorder and Transition-Aged Youth. Current psychiatry reports. 2018; 20(11): 103.

3. DeFilippis M, Wagner KD. Treatment of autism spectrum disorder in children and adolescents. Psychopharmacology bulletin. 2016; 46(2): 18.

4. Coskun M, Mukaddes NM. Mirtazapine treatment in a subject with autistic disorder and fetishism. Journal of child and adolescent psychopharmacology. 2008; 18(2): 206-9.

5. Realmuto GM, Ruble LA. Sexual behaviors in autism: problems of definition and management. Journal of autism and developmental disorders. 1999; 29(2): 121-7.
6. Jones MC, Okere K. Treatment of hypersexual behavior with oral estrogen in an autistic male. Southern medical journal. 2008; 101(9): 959-60.

7. Nguyen $M$, Murphy $T$. Mirtazapine for excessive masturbation in an adolescent with autism. Journal of the American Academy of Child \& Adolescent Psychiatry. 2001; 40(8): 868-9.

8. Albertini G, Polito E, Sarà M, Di Gennaro G, Onorati P. Compulsive masturbation in infantile autism treated by mirtazapine. Pediatric neurology. 2006; 34(5): 417-8.

9. Coskun M, Karakoc S, Kircelli F, Mukaddes NM. Effectiveness of mirtazapine in the treatment of inappropriate sexual behaviors in individuals with autistic disorder. Journal of child and adolescent psychopharmacology. 2009; 19(2): 203-6.

10. Deepmala, Agrawal M. Use of propranolol for hypersexual behavior in an adolescent with autism. Annals of Pharmacotherapy. 2014; 48(10): 1385-8.

11. Chen F, Grandjean C, Richard S. Pharmacological management of inappropriate sexual behaviors in youth with autism spectrum disorder: A case study and review of the literature. Neuropsychiatrie de I'Enfance et de I'Adolescence. 2016; 64(3): 163-7.

12. Ayaydın H, Ulgar ŞB. Diagnosis and treatment of early childhood masturbation in a case of autism spectrum disorder: a case report. 2018.

13. Hergüner S. Otistik bozuklugu olan çocuk ve ergenlerde asiri masturbasyon davranisi: Üç olguda essitalopram etkinligi/Excessive masturbation in children and adolescents with autistic disorder: efficacy of escitalopram in three cases. Anadolu Psikiyatri Dergisi. 2009; 10: S102.

14. Dincer M, Gul A, Gul H, Aydın MS, Bodur S, Tas Torun Y, Congologlu MA, Ozmenler KN. Mirtazapine-related manic/hypomanic shift: mini review and case report. Neurological Sciences. 2018; 31: 209-14. 